\title{
ENSINO DA NORMA CULTA DA LÍNGUA COMO RECONHECIMENTO DA LEGITIMIDADE DE TRABALHO E AÇÃO PEDAGÓGICA
}

TEACHING OF THE STANDARD LANGUAGE AS RECOGNITION OF THE LEGITIMACY OF WORK AND PEDAGOGICAL ACTION

\section{ENSEÑANZA DE LAS REGLAS DE LA LENGUA CULTA COMO RECONOCIMIENTO DE LA LEGITIMIDAD DEL TRABAJO Y DE LA ACCIÓN PEDAGÓGICA}

\author{
José Maria Baldino ${ }^{1}$ \\ Pontifícia Universidade Católica de Goiás, Professor do Programa de Pós-graduação em \\ Educação
}

\section{Elaine Nicolodi ${ }^{2}$}

Faculdade Araguaia, Professora titular; Secretaria de Estado da Educação de Goiás, Professora

\section{Ronaldo Rosa dos Santos Júnior ${ }^{3}$}

Faculdade Araguaia, Professor e Coordenador do Curso de Tecnologia em Gestão Comercial

Resumo: Neste artigo aborda-se o fato de o professor, em seu discurso na sala de aula, exercer a autoridade pedagógica em uma determinada ação pedagógica, como, por exemplo, ao ensinar a norma culta da língua. $\mathrm{O}$ ensino da gramática normativa se transformou em "mito" nas instituições escolares. Pierre Bourdieu discute a legitimidade da ação pedagógica, em parceria com Passeron, na obra $A$ reprodução. Em outra obra, A economia das trocas linguísticas, trata sobre as relações de comunicação realizadas por meio dessas trocas, afirmando serem elas relações de poder simbólico. Essas duas obras foram escolhidas para que seja feita uma discussão a respeito do ensino da norma culta da língua nas escolas, como forma de imposição legítima de uma

\footnotetext{
${ }^{1}$ Doutor em Educação pela Universidade Estadual Paulista Júlio de Mesquita Filho; Mestre em Educação Escolar Brasileira pela Universidade Federal de Goiás.

${ }^{2}$ Doutora em Educação pela Universidade Federal de Goiás; Mestre em Educação pela Pontifícia Universidade Católica de Goiás.

${ }^{3}$ Doutor em Educação pela Pontifícia Universidade Católica de Goiás; Mestre em Gestão de Patrimônio Cultural pela Pontifícia Universidade Católica de Goiás.
} 
formação homogênea. Pretende-se apresentar como o conjunto de agentes do campo educacional está consciente ou inconscientemente subordinado às forças de imposição do arbitrário cultural dominante, movido por interesses comuns ou individuais, como, por exemplo, o êxito nos exames, em relação ao domínio ou não dessa língua. Palavras-chave: Campo educacional. Exames. Legitimidade. Norma culta. Poder simbólico.

Abstract: This paper brings the fact that the teacher, in his speech in the classroom, exercises pedagogical authority in a particular pedagogical action as, for example, teaching the standard language. The teaching of normative grammar has become a "myth" in school institutions. Pierre Bourdieu discusses the legitimacy of the pedagogical action, in partnership with Passeron, in the reproduction work. In another work, The Economics of Language Exchange, it deals with the relations of communication made through these exchanges, affirming that they are relations of symbolic power. These two works were chosen to that a discussion is made about the teaching of the cultured norm of the language in the schools, as a form of legitimate imposition of a homogeneous formation. It is intended to present how the set of agents of the educational field is consciously or unconsciously subordinated to the imposing forces of the dominant cultural arbitrary, driven by common or individual interests, such as success in examinations, in relation to the domain or not of that language.

Keywords: Educational field. Exams. Legitimacy. Standard language. Symbolic power.

Resumen: este artículo aborda el hecho de que el profesor, en su discurso en el aula, ejerce la autoridad pedagógica en una acción pedagógica concreta, como puede ser al enseñar las reglas de la lengua culta. La enseñanza de las reglas gramaticales se ha convertido en "mito" en las instituciones educativas. Pierre Bourdieu discute la legitimidad de la acción pedagógica, en colaboración con Passeron, en su obra La reproducción. En otro trabajo, La economía de los cambios lingüisticos, trata las relaciones de comunicación realizadas a través de cambios, afirmando que estos cambios son relaciones de poder simbólico. Estas dos obras fueron escogidas para hacerse una discusión sobre la enseñanza de las reglas de la lengua culta en las escuelas, como forma de imposición legítima de una formación homogénea. Se pretende presentar como el conjunto de agentes del campo educativo están, consciente o inconscientemente, subordinados de forma arbitraria a las fuerzas de imposición de las fuerzas culturales dominantes, impulsados por intereses comunes o individuales, tales como, por ejemplo, el éxito en los exámenes, en relación al dominio o no de esta lengua. 
Palabras clave: Campo educativo. Exámenes. Legitimidad. Reglas cultas. Poder Simbólico.

\section{INTRODUÇÃO}

Aula de Português

A linguagem na ponta da língua, tão fácil de falar e de entender.

A linguagem na superfície estrelada de letras, sabe lá o que ela quer dizer?

Professor Carlos Góis, ele é quem sabe, e vai desmatando o amazonas de minha ignorância. Figuras de gramática, esquipáticas, atropelam-me, aturdem-me, seqüestram-me.

Já esqueci a língua em que comia, em que pedia para ir lá fora, em que levava e dava pontapé, a língua, breve língua entrecortada do namoro com a prima.

O português são dois; o outro, mistério. (ANDRADE, 1999, p. 86).

Como ocorre o ensino da norma culta da língua? Qual é o discurso de autoridade do professor em relação a esse ensino? Busca-se um aprendizado significativo para os alunos ou essa escolha apenas faz parte da lista de conteúdos dos processos seletivos? Propõe-se, neste texto, discutir a respeito de algumas dessas questões. Para isso, é considerado como se comportam os agentes que fazem parte do campo educacional, de que forma são legitimados seus interesses em comum e como ocorre a disputa por tais interesses.

Parte-se, então, da hipótese de que no campo educacional há um quadro de informações legítimas que devem ser repassadas aos alunos pelos professores. Em se tratando do tema específico deste texto, a norma culta da língua materna (escrita), considera-se que os alunos estariam dispostos a reconhecer esse tipo de linguagem como a correta e negar as demais. 
Em uma disputa por manter seu poder no campo educacional, o professor, em seu discurso na sala de aula, exerce a autoridade pedagógica ao ensinar a norma culta da língua. Em razão disso, o ensino da gramática normativa se transformou em "mito" na escola, conforme diz o próprio Carlos Drummond de Andrade no poema da epígrafe: "Professor Carlos Góis, ele é quem sabe [...]"

Com base nessa "autoridade", serão comentadas algumas proposições a respeito do ensino da norma culta da língua, bem como a discussão feita por Pierre Bourdieu sobre a legitimidade da ação pedagógica. Considera-se, ainda, que "As normas designam as regras e usos socialmente prescritos, caracterizando as práticas de uma coletividade ou de um grupo específico: linguagem, regras de polidez, comportamentos corporais, etc.” (BONNEWITZ, 2003, p. 76). Em razão disso, escolheu-se trabalhar com Bourdieu e decorre daí a necessidade de se mencionar seus dois conceitos principais: campo e habitus. Aqui se optou pelo campo educacional.

\title{
2 O ENSINO DA DISCIPLINA ESCOLAR LÍNGUA PORTUGUESA
}

De acordo com a Lei de Diretrizes e Bases da Educação Nacional (LDB) n. 9.394/1996,

\begin{abstract}
Art. 26. Os currículos do ensino fundamental e médio devem ter uma base nacional comum, a ser complementada, em cada sistema de ensino e estabelecimento escolar, por uma parte diversificada, exigida pelas características regionais e locais da sociedade, da cultura, da economia e da clientela.

$\S 1^{\circ}$ Os currículos a que se refere o caput devem abranger, obrigatoriamente, o estudo da língua portuguesa e da matemática [...]

Art. 36. O currículo do ensino médio observará o disposto na Seção I deste Capítulo e as seguintes diretrizes:

I - destacará a educação tecnológica básica, a compreensão do significado da ciência, das letras e das artes; o processo histórico de transformação da sociedade e da cultura; a língua portuguesa como instrumento de comunicação, acesso ao conhecimento e exercício da cidadania. (BRASIL, 1996, grifo nosso).
\end{abstract}

Essa obrigatoriedade do ensino de língua materna nas escolas está presente na própria Constituição Federal (BRASIL, 1988): “Art. 13. A língua portuguesa é o idioma oficial da República Federativa do Brasil [...] Art. 210. $\S 2^{\circ} \mathrm{O}$ ensino fundamental regular será ministrado em língua portuguesa, assegurada às comunidades indígenas também a utilização de suas línguas maternas e processos próprios de aprendizagem." 
A menção ao nível médio de ensino já estava presente em uma carta de Padre Manuel de Nóbrega, de 15 de junho de 1553, quando se refere "a uma aula de Gramática Latina freqüentada somente pelos alunos mais inteligentes da Escola de São Vicente." (TOBIAS, 1986, p. 47). Assim, no período dos jesuítas, também era obrigatório o ensino da língua materna e, além disso, o ensino do latim.

Segundo Bourdieu (1998, p. 32):

\begin{abstract}
A língua oficial está enredada com o Estado, tanto em sua gênese como em seus usos sociais. É no processo de constituição do Estado que se criam as condições da constituição de um mercado lingüístico unificado e dominado pela língua oficial: obrigatória em ocasiões e espaços oficiais (escolas, entidades públicas, instituições políticas etc.), esta língua de Estado torna-se a norma teórica pela qual todas as práticas lingüísticas são objetivamente medidas.
\end{abstract}

Se a língua "oficial" é a exigência do Estado, nada mais óbvio que as escolas ensinarem essa língua como forma de imposição, assim, a língua coloquial do convívio familiar torna-se inapropriada na sala de aula, passando o professor a legitimar em sua ação pedagógica o estudo de uma "nova" língua. De acordo com Bourdieu e Passeron (1982, p. 64), "o sistema de ensino reproduz a cultura, no entanto, dissimula essa ação, ou seja, numa aparente neutralidade pratica a violência simbólica, impondo, no caso aqui mencionado, um ensino homogêneo da língua pelos seus agentes."

Quando se refere a agente, é em razão de se considerar professores e alunos integrantes de um campo em que prevalecem interesses comuns e também particulares. Segundo o próprio Bourdieu (1997, grifo nosso),

[...] quando descrevo o espaço social global como um campo, isto é, ao mesmo tempo, como um campo de forças, cuja necessidade se impõe aos agentes que nele se encontram envolvidos, e como um campo de lutas, no interior do qual os agentes se enfrentam, com meios e fins diferenciados conforme sua posição na estrutura do campo de forças, contribuindo assim para a conservação ou a transformação de sua estrutura. (BOURDIEU, 1997, p. 50).

Então, quanto ao campo educacional, considera-se que seus agentes possuem interesses em disputa e interesses em comum, e opta-se por uma moeda do campo, ou seja, uma concepção legítima da educação e cada agente quer legitimar a sua concepção. Para se sobressair no campo, os agentes utilizam algumas estratégias, no caso da sala de aula, por exemplo, muitas vezes o professor mais carrasco, aquele que humilha o aluno que fala "errado", é o mais valorizado. 
A escola de educação básica no Brasil, sobretudo em seus anos finais, o ensino médio, tem um discurso de ensino preparatório, seja para uma profissão, seja para o prosseguimento nos estudos.

Não é somente hoje que essa etapa costuma pautar seus currículos em razão de avaliações externas; por exemplo, com a criação de cursos superiores, no período da vinda da Família Real, em 1808, o acesso a eles passou a influenciar a estrutura e a organização da escola secundária. Dessa forma, "o ensino secundário destinava-se ao preparo dos candidatos ao ensino superior, razão por que seu conteúdo se estruturou em função deste [...]” (ROMANELLI, 1994, p. 39).

Posterior à LDB (1996), vieram as Diretrizes Curriculares Nacionais para o Ensino Médio (DCNEM) e também os Parâmetros Curriculares Nacionais do Ensino Médio (PCNEM). Neles, as disciplinas foram organizadas em três grandes áreas do conhecimento; nesses documentos não são sugeridos conteúdos curriculares, mas, sim, competências e habilidades a serem desenvolvidas ao longo do ensino médio.

Em se tratando especificamente dos estudos em Língua Portuguesa, entre as competências estabelecidas, afirma-se: “Compreender e usar a Língua Portuguesa como língua materna, geradora de significação e integradora da organização do mundo e da própria identidade.” E também: "Considerar a Língua Portuguesa como fonte de legitimação de acordos e condutas sociais e como representação simbólica de experiências humanas manifestas nas formas de sentir, pensar e agir na vida social." (BRASIL, 2000, p. 24).

Os PCNEM não apresentam caráter de obrigatoriedade e, portanto, pressupõe-se que serão adaptados às necessidades de cada escola; no entanto, é uma forma de busca de formação homogênea, uma vez que

[...] o Estado tem a capacidade de regular o funcionamento dos diferentes campos, seja por meio de intervenções financeiras (como, no campo econômico, os auxílios públicos a investimentos ou, no campo cultural, os apoios a tal ou qual forma de ensino), seja através de intervenções jurídicas (como as diversas regulamentações do funcionamento de organizações ou do comportamento dos agentes individuais). (BOURDIEU, 1997, p. 51).

Nesse sentido, fica muito evidente na ação pedagógica do professor o papel reprodutivista da escola, já que tal "homogeneidade" não existe de fato, seja quando se considera uma sala de alunos - entre eles há diferença de classe, idade, sexo, et- 
nia, consequentemente, diferentes relações sociais - , seja uma escola pública e outra particular.

Ao impor certo tipo de ensino de conteúdo, da gramática da norma culta, por exemplo, o professor necessita considerar não apenas o que se exige nos documentos oficiais e vem explicitamente expresso nos manuais dos livros didáticos, ou o que será exigido em editais de seleção para o curso superior.

O ensino da língua deve ir mais além; não é possível deixar de analisar na escrita dos alunos as suas intenções de autoria no discurso, em que contextos estão buscando se apropriarem das argumentações, dos fatos; e não apenas considerar o bom uso da norma padrão de escrita. Ao fazer isso, o professor está apenas legitimando uma concepção de língua, aquela privilegiada pelas classes mais abastadas de capital cultural. Os resultados desse tipo de ensino são encontrados nos exames.

Em 1998, criou-se o Exame Nacional do Ensino Médio (ENEM); a prova era opcional e pretendia avaliar os alunos concluintes do ensino médio mediante uma matriz de competências e habilidades, assim como é proposto nos PCNEM. Eram 63 questões objetivas (múltipla escolha) nas áreas: Linguagens, Códigos e suas Tecnologias, Ciências Humanas e suas Tecnologias, Ciências da Natureza, Matemática e suas Tecnologias e a Redação (Quadro 1). A partir de 2009, o Exame passou a apresentar quatro provas objetivas, com 45 questões cada, nas áreas de Linguagens, Matemática, Ciências da Natureza e Ciências Humanas, além da Redação.

Quadro 1 - Matriz de Competências da Prova de Redação

\begin{tabular}{|l|l|}
\hline \multicolumn{2}{|c|}{ COMPETÊNCIAS } \\
\hline I & Demonstrar domínio da norma padrão da língua escrita. \\
\hline II & $\begin{array}{l}\text { Compreender a proposta de redação e aplicar conceitos das várias áreas de conheci- } \\
\text { mento para desenvolver o tema, dentro dos limites estruturais do texto dissertativo- } \\
\text {-argumentativo. }\end{array}$ \\
\hline III & $\begin{array}{l}\text { Selecionar, relacionar, organizar e interpretar informações, fatos, opiniões e argumen- } \\
\text { tos em defesa de um ponto de vista. }\end{array}$ \\
\hline IV & $\begin{array}{l}\text { Demonstrar conhecimento dos mecanismos linguísticos necessários para a construção } \\
\text { da argumentação. }\end{array}$ \\
\hline V & $\begin{array}{l}\text { Elaborar proposta de solução para o problema abordado, respeitando os valores huma- } \\
\text { nos e considerando a diversidade sociocultural. }\end{array}$ \\
\hline
\end{tabular}

Fonte: Brasil (2011). 
Entre as competências da prova de redação, novamente aparece "Dominar a norma culta da Língua Portuguesa.” (BRASIL, 2011). Segundo Ferreira (1988, p. 182, grifo do autor), “Dominar v. t. 1. Exercer autoridade, poder, influência ou domínio sobre. 2. Reprimir. 3. Preponderar. P. 4. Conter-se. § dominação sf."

Então, com a intenção de "dominar a língua", muitos professores procuram em sua prática pedagógica exercer a autoridade de "ensinadores" da gramática da norma culta, ${ }^{4}$ seja durante suas aulas expositivas, nas análises de textos consagrados da literatura nacional, seja quando estão "corrigindo" as produções escritas de seus alunos.

Para Bourdieu (1998, p. 35): “O código (na acepção de cifra) que rege a língua escrita, identificada à língua correta, por oposição à língua falada (conversational language), implicitamente tida como inferior, adquire força de lei no e pelo sistema de ensino."

Com o "poder da lei", muitos professores esquecem que seus alunos também utilizam a língua em outras situações cotidianas e não apenas na sala de aula, sobretudo nas redes sociais, não sendo sempre a norma culta a preferida.

Além disso, em uma situação de produção de texto em um Exame, considera-se que não é apenas dominar ou não a norma culta (Competência I) a única dificuldade dos alunos, a maioria deles costuma não ser preparado na escola para desenvolver suas próprias opiniões, reproduzindo o discurso do professor para obter melhores resultados. Então, quando se deparam em um Exame com a proposta de tentar intervir no problema apresentado (Competência V) e sem conhecer o leitor de seu texto, sentem-se acuados.

Há, nesse caso, um grande abismo entre o que ensina o professor e o que os alunos aprendem, tornando-se, muitas vezes, insignificante ficar memorizando uma infinidade de regras que fazem parte dos textos escritos. Em nome do ensino da norma culta, a gramática virou mito na escola. Além disso,

\begin{abstract}
Na linguagem escrita, o pensamento se expressa através de significados formais das palavras, dependendo muito mais delas que na linguagem oral. $\mathrm{Na}$ linguagem escrita, pela ausência do interlocutor, o sentido daquilo que se escreve deve ser totalmente explícito, por isso requer mais palavras para expressar uma idéia do que na linguagem oral, em que os interlocutores estão participando do mesmo contexto [...] (ZUIN; REYES, 2010, p. 66).
\end{abstract}

\footnotetext{
${ }^{4}$ Nas discussões aqui apresentadas, optou-se, apenas, por se tratar de uma prática pedagógica na qual prevalece o ensino da norma culta, sem discorrer sobre outras ações pedagógicas que considerem um ensino mais contextualizado, pela intenção de não conceber a gramática normativa como o centro das discussões nas aulas de Língua Portuguesa.
} 
Sem reconhecerem a estrutura da língua e seus usos, muitos alunos ficam presos à memorização de regras; e os professores, fazendo inúmeras marcações em vermelho nos textos daqueles, esquecendo, na maioria das vezes, de se preocuparem com a estruturação, a coesão, a coerência, as escolhas lexicais apropriadas. Os alunos estão mais preocupados em "[...] produzir discursos formalmente corretos, mas semanticamente vazios.” (BOURDIEU, 1998, p. 28).

Em nome do reconhecimento da legitimidade da informação transmitida, o professor toma "seu poder" e desconhece a dificuldade que a maioria dos alunos tem de utilizar os códigos da norma culta, uma vez que não faz parte das escolhas familiares de uso da língua, sobretudo quando se trata da classe mais baixa, pouco escolarizada, pois "entre todas as ações pedagógicas que sofremos, as mais decisivas são as mais precoces, as que sofremos durante a infância, e que tiveram como resultado inculcar-nos um habitus primário" (BONNEWITZ, 2003, p. 78, grifo do autor), como ocorre no processo de aquisição da linguagem/língua (culta ou não).

Esse processo se inicia no convívio familiar, “a interiorização [desse novo habitus] permite agir sem ser obrigado a lembrar-se explicitamente das regras que é preciso observar para agir.” (BONNEWITZ, 2003, p. 77). Diferente do que ocorre na aprendizagem da língua na escola, que quase sempre desconsidera que, "além de um léxico e de uma sintaxe, cada indivíduo herda, de seu meio, uma certa atitude em relação às palavras e ao seu uso [...]” (BOURDIEU, 2011, p. 56).

Dessa forma, "toda ação pedagógica (AP) é objetivamente uma violência simbólica enquanto imposição, por um poder arbitrário, de um arbitrário cultural." (BOURDIEU; PASSERON, 1982, p. 20, grifo do autor). Essa ação dá legitimidade à autoridade pedagógica, e, ao aceitar a legitimidade do outro, nega-se a própria legitimidade, nesse caso, opta-se pelo uso de um código que se reconhece. Assim,

Todo poder de violência simbólica, isto é, todo poder que chega
a impor significações e a impô-las como legítimas, dissimulan-
do as relações de força que estão na base de sua força, acres-
centa sua própria força, isto é, propriamente simbólica, a essas
relações de força. (BOURDIEU; PASSERON, 1982, p. 19).

Essa violência fica evidente ao se observar que o ensino ainda é privilégio da burguesia, daqueles que sabem, que se sobressaem melhor nas avaliações, uma vez que muitos alunos das classes mais altas, das escolas particulares especialmente, já trazem do seu convívio familiar o capital linguístico e somente o reforçam na escola e têm acesso a outras fontes de conhecimento, a um maior alcance a outros bens cultu- 
rais. Além disso, quando em dificuldade de aprendizagem, podem contar com a orientação dos pais, quase sempre bem formados, com aulas de reforço, etc. E também

\begin{abstract}
[...] graças às interações de que elas gozam em suas famílias, as crianças das categorias abastadas manifestam, em média, um nível de desenvolvimento operatório mais precoce, assim como um tipo de linguagem mais adaptado às exigências da escola. Este capital existe também sob forma objetivada no ambiente dessas crianças: livros, obras de arte, viagens, acesso à mídia [...] (BONNEWITZ, 2003, p. 115).
\end{abstract}

As próprias escolas particulares oferecem possibilidades diferenciadas aos alunos, com aulas extras, passeios culturais, palestras, etc. Por ser uma instituição paga, os pais, na maioria das vezes, exigem muito mais dos filhos, não apenas pelo aspecto financeiro, mas, sobretudo, como forma de mostrar à sociedade seus bons resultados, elevando as qualidades intelectuais de seus filhos publicamente, como, por exemplo, outdoors de escolas com alto número de aprovados em universidades públicas bem conceituadas. E a violência simbólica pode ser ainda mais percebida com o discurso "dissimulado" de igualdade de acesso. Uma vez que

Os campos não são espaços com fronteiras estritamente delimitadas, totalmente autônomos. Eles se articulam entre si [...] existe uma interpenetração dos campos. Assim, a lógica de funcionamento do campo econômico tende cada vez mais a permear outros campos [...] (BONNEWITZ, 2003, p. 62-63).

E essa "interpenetração" também ocorre no campo educacional, pois quanto maior o prestígio da instituição, melhor acessibilidade ao mercado de trabalho; quanto mais instrução, melhores salários.

O bom desempenho ou não pode determinar o comportamento do aluno em sala de aula; assim, "os locutores desprovidos de competência legítima se encontram de fato excluídos dos universos sociais onde ela é exigida, ou então, se vêem condenados ao silêncio.” (BOURDIEU, 1998, p. 42).

Quando são observados os resultados do ENEM, grande parte dos alunos das escolas particulares ocupa a classificação mais alta, mesmo com o discurso oficial de democratização do ensino, de inclusão. No entanto, a baixa qualidade no ensino na maioria das escolas públicas, por inúmeros motivos não mencionados aqui, reforça ainda mais a exclusão. 
Enquanto mercado lingüístico estritamente sujeito aos veredictos dos guardiães da cultura legítima, o mercado escolar encontra-se estritamente dominado pelos produtos lingüísticos da classe dominante e tende a sancionar as diferenças de capital preexistentes. [...] Os desvios iniciais tendem, portanto, a se reproduzir, pelo fato de que a duração da inculcação tende a variar tanto quanto seu rendimento, fazendo com que os menos inclinados e os menos aptos a aceitar e a adotar a linguagem escolar sejam também os que se expõem menos tempo a essa linguagem, bem como aos controles, correções e sanções escolares. (BOURDIEU, 1998, p. 49-50).

O que ocorre, de fato, é uma exclusão "branda", "contínua", "insensível", “despercebida" (NOGUEIRA; CATANI, 2011, p. 13), confirmando o reprodutivismo, o não acesso a todos, deixando evidente que "dominantes" e "dominados" ocupam espaços diferentes na sociedade.

Assim, a escola continua mantenedora de privilégios. Ao demonstrar bons resultados, determinada escola passa a ser "objeto de desejo" por aqueles que querem obter o sucesso (serem aprovados), uma vez que os alunos que conseguem melhores resultados irão para as melhores universidades (preferencialmente públicas federais) ou serão selecionados para os melhores cargos, ou seja,

[...] Os exames ou os concursos justificam em razão de divisões que não necessariamente têm a racionalidade por princípio, e os títulos que sancionam seus resultados apresentam como garantia de competência técnica certificados de competência social, nisso muito próximos dos títulos de nobreza. (BOURDIEU, 1997, p. 38, grifo do autor).

\title{
Quando a mídia divulga tais resultados, fica evidente que
}

\begin{abstract}
A dominação não é o efeito direto e simples da ação exercida por um conjunto de agentes ("a classe dominante") investidos de poderes de coerção, mas o efeito indireto de um conjunto complexo que se engendram na rede cruzada de limitações que cada um dos dominantes, dominado assim pela estrutura do campo através do qual se exerce a dominação, sofre de parte de todos os outros. (BOURDIEU, 1997, p. 52, grifo do autor).
\end{abstract}

Assim, os pais, muitas vezes, são influenciados por esses números ao escolherem a escola de seus filhos, e os que detêm capital econômico optam por aquelas de maior prestígio social, mais caras. 
[...] Além disso, os pais que desfrutam de um capital cultural e social elevado dispõem de um maior número de fontes de informação sobre os cursos e os estabelecimentos. São capazes de aplicar uma estratégia que permita garantir o sucesso escolar e social de seus descendentes, mantendo a raridade distintiva do título acadêmico possuído. Essas estratégias permitem explicar por que o acesso às instituições mais prestigiosas, que levam às posições de poder, continua sendo privilégio das categorias dominantes. Inversamente, os alunos oriundos das categorias mais desfavorecidas são orientados para cursos de relegação. (BONNEWITZ, 2003, p. 127).

$\mathrm{Na}$ análise do sistema de ensino, Bourdieu (1997) acredita que a escola serve para manter a estrutura de classes, não para mudar. Os Exames externos tendem a demonstrar a reprodução, uma vez que muitas escolas tentam resistir ao "conteudismo" ou à preparação para seleções.

Com isso, o sistema escolar

[...] mantém a ordem preexistente, isto é, a separação entre os alunos dotados de quantidades desiguais de capital cultural. Mais precisamente, através de uma série de operações de seleção, ele separa os detentores de capital cultural herdado daqueles que não o possuem. Sendo as diferenças de aptidão inseparáveis das diferenças sociais conforme o capital herdado, ele tende a manter as diferenças sociais preexistentes. (BOURDIEU, 1997, p. 37).

O discurso do Governo é de uma tentativa de apresentar a aparência de escola igualitária, com a democratização do acesso, no entanto, em razão das condições sociais dos alunos e até mesmo dos próprios professores, a permanência e o sucesso não são garantidos de maneira igualitária.

De todos os obstáculos culturais, aqueles que se relacionam com a língua falada no meio familiar são, sem dúvida, os mais graves e os mais insidiosos, sobretudo nos primeiros anos da escolaridade, quando a compreensão e o manejo da língua constituem o ponto de atenção principal na avaliação dos mestres. Mas a influência do meio lingüístico de origem não cessa jamais de se exercer, de um lado porque a riqueza, a fineza e os estilos da expressão sempre serão considerados, implícita ou explicitamente, consciente ou inconscientemente, em todos os níveis do cursus, e, ainda que em graus diversos, em todas as carreiras universitárias, até mesmo nas científicas. (BOURDIEU, 2011, p. 46). 
Dessa forma, professores e alunos, muitas vezes, não são conscientes da reprodução e desconhecem a violência simbólica à qual estão submetidos em razão da aparência de neutralidade do sistema de ensino, o que deixa ainda mais evidente a busca pela autoridade do professor, legitimando o papel reprodutivo da escola, que desconsidera o contexto particular de cada aluno.

Ao ensinar a língua materna, por exemplo, o professor busca legitimar sua autoridade com o discurso de preparar seus alunos de forma que obtenham melhores resultados e não com a preocupação a respeito de eles estarem ou não aprendendo significativamente, por isso a menção feita aos processos seletivos, sobretudo o ENEM, como forma de apenas ser um modelo de ensino reprodutivista também em relação ao ensino da norma culta. Para Bourdieu e Passeron (1982, p. 75),

[...] só pelo fato de que existe e subsiste como instituição, ele [o sistema de ensino institucionalizado] implica as condições institucionais do desconhecimento da violência simbólica que exerce, isto é, porque os meios institucionais dos quais dispõe enquanto instituição relativamente autônoma, detentora do monopólio do exercício legítimo da violência simbólica, estão predispostos a servir também, sob a aparência da neutralidade, os grupos ou classes dos quais ele reproduz o arbitrário cultural (dependência pela independência).

No caso do ENEM, durante um tempo ele não era "matéria do dia" nas escolas, sobretudo particulares, mas quando passou a ser porta de acesso a inúmeras instituições de ensino superior, incluindo as públicas, a maioria aderiu à preparação de seus alunos, pois “o Estado intervém como regulador, cujas decisões de política econômica e social fixam ou modificam as regras do jogo próprio ao campo." (BONNEWITZ, 2003, p. 65).

Em se tratando especificamente do ensino da norma culta e do não reconhecimento de outras formas tidas como não legítimas de expressão, a língua é considerada um veículo de poder, quem a domina, seja na fala, seja na escrita, tem direito de deliberar sobre os demais, seja no discurso político, seja no religioso e no midiático. Desse modo, a escola, na maioria das vezes, tende a naturalizar o ensino da norma culta (oficial) como o único com valor de sucesso, "[...] a língua [...] é com certeza o suporte por excelência do sonho de poder absoluto.” (BOURDIEU, 1998, p. 28).

No ensino tradicional da gramática da norma culta, estanque, descontextualizado, considera-se a língua apenas como produto acabado, presente nas enciclopédias, nos dicionários, nos livros didáticos, etc., porém, corre-se o risco de considerá-la um código técnico, pois 
[...] a linguagem é o primeiro mecanismo formal cujas capacidades geradoras são ilimitadas. Não há nada que não se possa dizer, e pode-se dizer o nada. Pode-se enunciar tudo na língua, isto é, nos limites da gramaticalidade. [...] que as palavras podem ter sentido sem remeter a coisa alguma [...] (BOURDIEU, 1998, p. 28).

Dessa forma, “[...] a linguagem não é apenas a língua e seu sistema de códigos; ao contrário, é uma criação cultural viva e que permite aos indivíduos interagir com o meio e consigo mesmo." (ZUIN; REYES, 2010, p. 28).

Por isso, cada campo tem seu código linguístico; ao ouvir uma conversa em um centro cirúrgico, por exemplo, as escolhas lexicais ali presentes são diferentes daquelas de uma reunião de corretores da bolsa de valores, e a sociedade as considera aceitáveis ou não, apropriadas ou não, pois “'[...] a linguagem na qual nós nos expressamos não é sociologicamente neutra; ela encerra, no seu vocabulário e na sua sintaxe, uma concepção de mundo." (BONNEWITZ, 2003, p. 30).

Este "sentido do posicionamento" lingüístico comanda o grau de coerção que um determinado campo fará pesar sobre a produção de discursos, impondo a alguns o silêncio ou uma linguagem hipercontrolada, enquanto faculta a outros as liberdades de uma linguagem desenvolta. Vale dizer, a competência, adquirida no contexto pela prática, comporta, de modo inarredável, o domínio prático de um uso da língua e o domínio prático das situações nas quais esse uso da língua é socialmente aceitável. (BOURDIEU, 1998, p. 70, grifo do autor).

Assim, há escolhas que deixam perceber a classe social, motivo quase sempre de crítica quando algum aluno se manifesta na sala de aula, demonstrando ter ou não competência linguística em relação ao uso da norma culta. Segundo Bourdieu (1998, p. 54):

As competências lingüísticas constituem capacidades de produção socialmente classificadas que caracterizam unidades lingüísticas de produção socialmente classificadas e, ao mesmo tempo, configuram capacidades de apropriação e de apreciação que, por sua vez, definem mercados eles mesmos socialmente classificados. [...] Não obstante, a relação de força lingüística não é completamente determinada apenas pelas forças lingüísticas em confronto [...]

Então, com a intenção de transformar todos em "bons" falantes do idioma, alguns professores preconizam os incansáveis exercícios de "passe para a norma 
culta", "identifique a sintaxe correta", etc. E o ensino da língua da escola, na maioria das vezes, justifica-se com o seguinte discurso do professor: "Isso será cobrado em processos seletivos." E, ainda,

[...] os trabalhos na área do ensino da língua preconizam o conhecimento da língua em detrimento do conhecimento de sua estrutura gramatical. Não que esse conhecimento não seja importante para a formação de um escritor competente, mas não é o único. [...] Saber gramática é importante, mas não como análise fragmentada de frases sem um determinado contexto. (ZUIN; REYES, 2010, p. 24-25).

Aqueles que não apresentam ter a "competência" de se expressar corretamente vão sendo excluídos, relegados, optam, muitas vezes, pela não continuidade dos estudos, escolhendo ocupações marginalizadas pela sociedade. Como aparece no poema Vício na fala, de Oswald de Andrade:

\author{
Para dizerem milho dizem mio \\ Para melhor dizem mió \\ Para pior pió \\ Para telha teia \\ Para telhado teiado \\ E vão fazendo telhados. (ANDRADE, 1971, p. 22).
}

Isso acontece porque na escola não se reconhece que determinado uso da linguagem representa um habitus, um pertencimento a determinado grupo, pois

Os habitus são princípios geradores de práticas distintas e distintivas - o que o operário come, e sobretudo sua maneira de comer, o esporte que pratica e sua maneira de praticá-lo, suas opiniões políticas e sua maneira de expressá-las diferem sistematicamente do consumo ou das atividades correspondentes do empresário industrial; mas são também esquemas classificatórios, princípios de classificação, princípios de visão e gostos diferentes. [...] Assim, por exemplo, o mesmo comportamento ou o mesmo bem pode parecer distinto para um, pretensioso ou ostentatório para outro e vulgar para um terceiro. (BOURDIEU, 1997, p. 22).

Com isso, o não uso da língua culta pode ser considerado vulgar quando se trata de um juiz proferindo uma sentença; parece ser pretensioso usar termos muito clássicos em meio a trabalhadores analfabetos ou distinto quando se trata de uma análise de obra literária, já que 
A cultura escolar é uma cultura particular, a da classe dominante, transformadora em cultura legítima, objetivável e indiscutível. Na verdade, ela é arbitrária e de natureza social, resultado de uma seleção que define o que é estimável, distinto, ou ao contrário, vulgar e comum. (BONNEWITZ, 2003, p. 114).

Por não considerarem quem são verdadeiramente seus alunos, alguns professores, ao indicar a leitura de alguma obra clássica literária, não discutem previamente com eles a respeito da erudição da língua que encontrarão, como se essa linguagem pertencesse ao meio dos alunos. Como não é de domínio deles, o conteúdo do texto fica prejudicado, pelo não entendimento linguístico, causando, até, aversão àquele tipo de leitura.

O que ocorre, na maioria das vezes, é que os alunos com mais dificuldade de expressão, ou seja, aqueles que em seu cotidiano não se apropriaram das inúmeras estratégias que a própria língua oferece, apresentam mais dificuldade na análise de textos, na compreensão do subentendido dos discursos midiáticos. Uma vez que

[...] O essencial na tarefa de descodificação não consiste em reconhecer a forma utilizada, mas compreendê-la num contexto preciso, isto é, compreender seu significado numa enunciação particular. Portanto, na prática viva da língua, a consciência lingüística do locutor e do receptor nada tem a ver com um sistema abstrato de formas normativas, mas apenas com a linguagem no sentido de conjunto dos contextos possíveis de uso de cada forma particular. (ZUIN; REYES, 2010, p. 77).

Então, não será na imposição de normas vazias de sentido que os alunos compreenderão de fato a língua, sobretudo sua norma culta, pois

Os educandos provenientes de famílias desprovidas de capital cultural apresentarão uma relação com as obras de cultura veiculadas pela escola que tende a ser desinteressada, laboriosa, tensa, esforçada, enquanto para os indivíduos originários de meios culturalmente privilegiados essa relação está marcada pelo diletantismo, desenvoltura, elegância, facilidade verbal "natural". Ocorre que, ao avaliar o desempenho dos alunos, a escola leva em conta sobretudo - consciente ou inconscientemente - esse modo de aquisição (e uso) do saber ou, em outras palavras, essa relação com o saber. (NOGUEIRA; CATANI, 2011, p. 9, grifo do autor).

Preocupados apenas com a resolução de exercícios de regras da gramática normativa, muitos alunos esquecem de buscar compreender, significativamente, a lín- 
gua. Quando em seu texto o aluno fixa, demasiadamente, sua atenção para o bom uso da gramática normativa, muitas vezes ou quase sempre, ele esquece de pensar com mais eficiência nas escolhas dos vocábulos utilizados, não se preocupando em pensar que tais escolhas podem demonstrar ao examinador de uma prova o quanto o seu discurso já é predeterminado, faltando sua "autoria".

Assim, demonstra que não possui apropriada capacidade de expressão, pois “[...] não existem mais palavras inocentes. [...] Cada palavra, cada locução ameaça assumir dois sentidos antagônicos conforme a maneira que o emissor e o receptor tiverem de interpretá-la.” (BOURDIEU, 1998, p. 27). Então, desconsidera-se que

[...] o poder das palavras reside no fato de não serem pronunciadas a título pessoal por alguém que é tão-somente "portador" delas. O porta-voz autorizado consegue agir com palavras em relação a outros agentes e, por meio de seu trabalho, agir sobre as próprias coisas, na medida em que sua fala concentra o capital simbólico acumulado pelo grupo que lhe conferiu o mandato e do qual ele é, por assim dizer, o procurador. (BOURDIEU, 1998, p. 89, grifo do autor).

Esse poder está relacionado ao fato de ter "voz", ou seja, se fazer ouvir pelo outro, ter domínio sobre ele, e não pode ser no "monologismo" de aulas expositivas que a aprendizagem da língua acontecerá de forma eficiente. Por isso, o aluno precisa se fazer ouvir; aquele que não fala/escreve tem dificuldade de expressar o que deseja, de exigir seus direitos, sobretudo em uma sociedade que requer o domínio de várias linguagens.

Ao considerar a "voz" dos alunos, também é preciso deixá-los falar sobre suas expectativas em relação ao modo como aprendem, à escola, ao acesso a outros níveis de ensino, à forma como gostariam de ser avaliados e como se sentem diante de tanta "pressão" para serem bem classificados em Exames.

\section{CONSIDERAÇÕES FINAIS}

Não se quer dizer com tudo isso que a norma culta da língua não seja ensinada, mas que a forma como esta é valorizada reforça ainda mais a desigualdade entre aqueles das classes privilegiadas, que desde a infância têm acesso a essa modalidade linguística, e os que não têm.

O papel da escola não pode ser apenas o de reproduzir as desigualdades culturais presentes na sociedade; o aluno precisa sentir-se inserido, apto a participar, 
fazer sua voz ser ouvida. O professor não pode apenas determinar o ensino de tal conteúdo como forma de legitimar sua autoridade, pois o diálogo constante com os alunos sobre o quê e como eles aprendem deve acontecer cotidianamente.

O que se aprende na escola não pode estar relacionado apenas aos conteúdos exigidos em exames; tem de ser significativo para a sua vida extraescolar. Dessa forma, no campo educacional, um de seus agentes, o professor, em sua ação pedagógica, muitas vezes, legitima a função da escola como reprodutivista, sobretudo quando fixa o ensino apenas na preparação para os exames.

Toda ação pedagógica é uma violência simbólica, por isso, a ação pedagógica do professor deve estar mais voltada para uma mediação entre o que precisa ser ensinado e o que os alunos necessitam aprender e não apenas a uma reprodução conteudista.

No entanto, o que deveria ocorrer de fato na escola é uma ação pedagógica que legitime uma verdadeira formação de alunos críticos, conscientes de sua realidade e que dominem a língua não apenas para êxito em Exames, mas para se fazerem ouvir na sociedade.

Em nome de o mundo social ser percebido como distinto, de tentar legitimar sua ação, muitas vezes, o professor impõe a língua oficial, não possibilitando ao aluno se manifestar de maneira simples, coloquial, levando-o ao silêncio.

\section{REFERÊNCIAS}

ANDRADE, C. D. de. Boitempo II. Rio de Janeiro: Record, 1999.

ANDRADE, C. D. de. Poesia e prosa. Rio de Janeiro: Nova Aguilar, 1992.

ANDRADE, O. de. Poesias reunidas. Rio de Janeiro: Civilização Brasileira, 1971.

BONNEWITZ, P. Primeiras lições sobre a sociologia de P. Bourdieu. Tradução Lucy Magalhães. Petrópolis: Vozes, 2003.

BOURDIEU, P. A economia das trocas lingüísticas: o que falar quer dizer. Tradução Sergio Miceli. São Paulo: Edusp, 1998.

BOURDIEU, P. A escola conservadora: as desigualdades frente à escola e à cultura. In: NOGUEIRA, M. A.; CATANI, A. (Org.). Escritos de educação. Petrópolis: Vozes, 2011.

BOURDIEU, P.; PASSERON, J.-C. A reprodução: elementos para uma teoria do sistema de ensino. Tradução Reynaldo Bairão. Rio de Janeiro: Francisco Alves, 1982. 
BOURDIEU, P. Razões práticas: sobre a teoria da ação. Tradução Mariza Corrêa. Campinas: Papirus, 1997.

BRASIL. Constituição. República Federativa do Brasil de 1988. Brasília, DF: Senado Federal, 1988. Disponível em: <http://www.senado.gov.br/legislacao/const/ con1988/CON1988_05.10.1988>. Acesso em: dez. 2016.

BRASIL. Lei n. 9.394, de 20 de dezembro de 1996. Estabelece as Diretrizes e Bases da Educação Nacional. Diário Oficial da União, Brasília, DF, 23 dez. 1996.

BRASIL. Ministério da Educação. A redação do Enem. Brasília, DF: INEP, 2011.

BRASIL. Parâmetros Curriculares Nacionais (Ensino Médio). Parte II - Linguagens, Códigos e suas Tecnologias. Brasília, DF: MEC, 2000.

FERREIRA, A. B. de H. Minidicionário da língua portuguesa. Rio de Janeiro: Nova Fronteira, 1988.

NOGUEIRA, M. A.; CATANI, A. Escritos de educação. Petrópolis: Vozes, 2011.

PETIT, V. As contradições de A Reprodução. Cadernos de Pesquisa, São Paulo, n. 43, p. 53-51, nov. 1982.

ROMANELLI, O. de O. História da educação no Brasil (1930-1973). Petrópolis: Vozes, 1994.

TOBIAS, J. A. História da educação brasileira. São Paulo: Ibrasa, 1986.

ZUIN, P. B.; REYES, C. R. O ensino da língua materna: dialogando com Vygotsky, Bakhtin e Freire. Aparecida: Ideias \& Letras, 2010.

Recebido em: 25 de janeiro de 2017 Aceito em: 25 de maio de 2017

Endereço para correspondência: Praça Universitária, s/n, 74605-010, Goiânia, Goiás, Brasil; jmbaldino@uol.com.br 
